\title{
FAKTOR RISIKO PENYEBAB TERJADINYA MALARIA DI INDONESIA : LITERATURE REVIEW
}

\author{
Risk Factors Causing Malaria in Indonesia : Literature Review
}

\author{
Tya Palpera Utami ${ }^{\text {** }}$ \\ Hamzah Hasyim ' \\ Ummi Kaltsum ' \\ Uthu Dwifitri ' \\ Yanti Meriwati ' \\ Yuniwarti ' \\ Yusro Paridah ' \\ Zulaiha ${ }^{\prime}$
}

IPasca Sarjana Program Magister Kesehatan Masyarakat Universitas Sriwijaya Palembang, Sumatera Selatan, Indonesia

*email:

I00|268212504I@student.unsri.ac.id

\section{Kata Kunci:}

Malaria

Faktor risiko

Perilaku

Lingkungan

\begin{abstract}
Abstrak
Malaria merupakan salah satu penyebab utama penyakit dan kematian di penjuru dunia. Di Indonesia, malaria masih menjadi masalah kesehatan masyarakat yangg serius yang dijumpai di berbagai wilayah. Risiko terjadinya malaria dipengaruhi banyak faktor, terutama jenis spesies nyamuk Anopheles, sikap manusia, serta faktor lingkungan tempat tinggal. Suatu perubahan asal faktor yang manapun, akan menyebabkan risiko terjadinya malaria. Tujuan dari penelitian ini untuk melihat gambaran dan faktor risiko malaria serta cara penanggulangan dan pengobatan penyakit malaria yang ada di Indonesia. Metode penelitian ini adalah penelitian deskriptif observasional dengan menggunakan desain literature review, dengan dengan databaseGoogle Scholar. Hasil pencarian yang memenuhi kriteria kemudian dilakukan analisis artikel. Malaria masih menjadi penyakit yang tinggi kasusnya di Indonesia untuk setiap tahunnya. Faktor - faktor penyebab malaria di Indonesia terdiri dari faktor perilaku dan sikap masyarakat (aktivitas malam hari, penggunaan obat anti nyamuk dan penggunaan kelambu), faktor lingkungan dan lingkungan fisik tempat tinggal (keberadaan kandang ternak, keberadaan semak-semak, keberadaan sawah berair, suhu, kelembaban, keberadaan kawat pada ventilasi, keadaan langit langit tempat tinggal, dan kerapatan dinding rumah). Salah satu cara untuk mencegah dan menanggulangi malaria dengan cara meningkatkan sanitasi individu dan lingkungannya.
\end{abstract}

Keywords: Malaria

Risk factor

Behaviour

Environment

\begin{abstract}
Malaria is one of the leading causes of disease and death worldwide. Around 2.4 billion people are at risk of malaria. In Indonesia, malaria is still a serious public health problem and is often found outside Java and Bali. The risk of malaria is determined by many factors, especially the type of Anopheles mosquito species, human behavior, and the presence of malaria parasites. A change of any of the factors, will affect the risk of malaria. The purpose of this study is to see an overview of the problem of malaria and the factors that cause malaria and how to prevent and treat malaria in Indonesia and the world. This research method is a descriptive observational study using a literature review design, with databases Google Scholar. The search results that meet the criteria are then analyzed for articles. Malaria is still a disease with high cases in Indonesia every year. Malaria can occur due to several factors. These factors are behavioral factors and community attitudes (night activities, use of mosquito repellent, use of mosquito nets), home environment factors (existence of cattle pens, presence of bushes and presence of watery rice fields); physical environmental factors of the house (temperature, humidity, the presence of wires in the ventilation, the presence of the ceiling of the house, and the density of the walls of the house).
\end{abstract}

(C) year The Authors. Published by Institute for Research and Community Services Universitas Muhammadiyah Palangkaraya. This is Open Access article under the CC-BY-SA License (http://creativecommons.org/licenses/bysa/4.0/). DOI: https://doi.org/10.33084/jsm.vxix.xxx.

\section{PENDAHULUAN}

Malaria menjadi salah satu penyebab utama penyakit dan kematian di penjuru dunia. Sekitar 2.4 miliar manusia berhadapan dengan risiko penyakit ini. Data yang ada sekarang ini, sebanyak 92 negara endemik malaria, yang diantaranya terdapat kantung- kantung penularan malaria di berbagai negara. Terdapat kasus klinis malaria yaitu sebanyak 300-500 juta, dimana lebih 
dari $90 \%$ terjadi di Sub Sahara Afrika [I]. Malaria merupakan penyakit menular yang menjadi masalah kesehatan di dunia, terutama di daerah beriklim tropis dan subtropis termasuk di Indonesia [2]. Di penjuru dunia, sebanyak 2 juta kematian setiap tahun yang disebabkan penyakit malaria, dan anak-anak dibawah lima tahun menjadi kasus kematian terbanyak. Dari seluruh penyakit menular, penderitaan dan kematian terbesar di dunia disebabkan penyakit malaria [I]. Kerugian yang ditimbulkan akibat penyakit malaria ini antara lain meningkatnya angka kematian ibu, angka kematian bayi, serta menurunnya produktivitas kerja [2].

Indonesia yang merupakan negara kepulauan memiliki iklim heterogen dan berpotensi pada perubahan iklim regional serta global. Penyebaran penyakit menular termasuk penyakit tular vektor nyamuk dipengaruhi perubahan iklim makro dan mikro. Malaria dikelompokkan ke dalam penyakit re-emerging disease yaitu penyakit yang muncul kembali akibat dari fenomena alam, salah satunya yakni faktor lingkungan meliputi iklim, suhu dan curah hujan [3]. Banyak faktor lain yang menentukan risiko terjadinya malaria terutama jenis spesies nyamuk Anopheles, sikap manusia, dan terdapat parasit malaria itu sendiri. Dari faktor manapun yang mengalami perubahan tersebut, akan mempengaruhi risiko terjadinya malaria. Risiko terjadinya malaria mengarah kepada dampak potensial perubahan global, yang saat ini menjadi perhatian seluruh dunia. Lingkungan geografis malaria telah berubah sebagai respon terhadap perubahan iklim, pola penggunaan lahan, biodiversitas(keanekaragaman hayati), dan struktur sosiodemografi (termasuk urbanisasi [I].

\section{METODOLOGI}

Metode yang digunakan adalah deskriptif observasional berupa tinjauan pustaka, tinjauan pustaka adalah tinjauan sintetik dan ringkasan dari apa yang diketahui dan tidak diketahui tentang topik kumpulan karya ilmiah, termasuk tempat kerja saat ini dalam pengetahuan yang ada [4]. Tinjauan pustaka menggunakan databaseGoogle Scholar. Artikel yang digunakan adalah artikel dari 10 tahun terakhir dengan total 30 artikel yang direview. Strategi pencarian artikel di Google Scholar menggunakan 4 kata kunci yaitu: “Malaria”; “Faktor Risiko"; "perilaku”; dan “lingkungan”. Adapun prosedur kerja dari literature review ini dapat dilihat pada Gambar I di bawah ini:

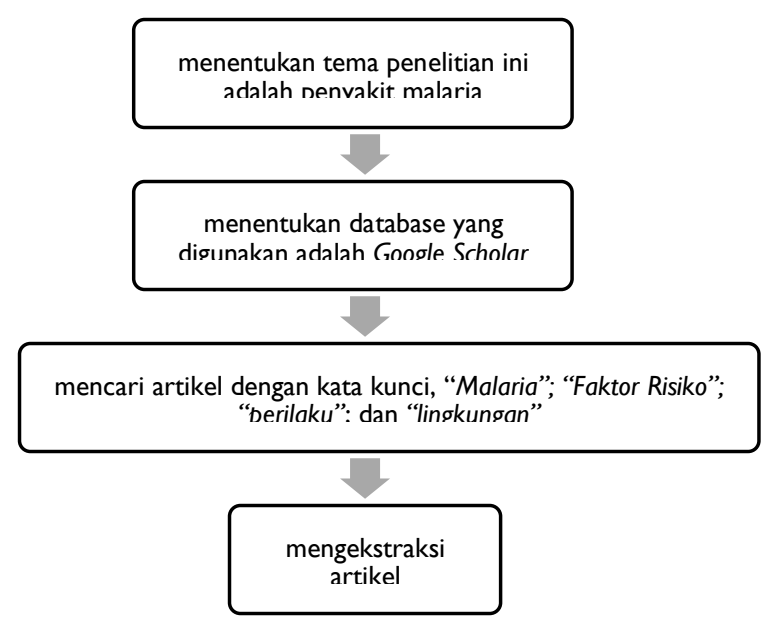




\section{HASIL DAN PEMBAHASAN.}

Tabel I. Artikel Terkait

Judul/Penulis/Tahun Sampel Hasil

$\begin{array}{cl}\text { Hubungan Iklim, Kepadatan } & \text { Nyamuk A. sundaicus adalah nyamuk yang jenisnya berpengaruh } d \\ \text { Nyamuk Anopheles dan Kejadian } & \text { Kecamatan Rajabasa dan Padang cermin cuaca tidak mempunyai hubungar } \\ \text { Penyakit Malaria/Suwito, } & \text { bermakna dengan banyaknya nyamuk Anopheles. Kelembaban udara dar } \\ \text { dkk/2010 } & \text { curah hujan mempunyai hubungan bermakna dengan kepadatan nyamuk } \\ & \text { Anopheles, sedangkan kepadatan nyamuk Anopheles mempunyai hubungar } \\ \text { bermakna dengan kasus malaria satu bulan berikutnya. }\end{array}$

Gambaran Pengetahuan

Masyarakat Tentang Penyakit

Malaria Di

Kecamatan Silian Raya

Kabupaten Minahasa
194 sampel

Seluruh responden pernah mendengar apa penyakit malaria (100\%) dar
paling banyak responden mendengar informasi tersebut dari penyuluhar
kesehatan (65.5\%). Untuk pengetahuan responden tentang gigitan nyamuk.
Tenggara/Cecilia,dkk/20I5
Penyebab penyakit malaria adalah karena gigitan nyamuk $(99,5 \%)$, karen ketidak tahuan (68\%) tentang jenis nyamuk penular penyebab penyaki1 malaria. Untuk Pengetahuan responden tentang waktu menggigit nyamuk penular penyebab penyakit malaria ialah malam hari (57.7\%).

Pengetahuan responden tentang tempat kumpulan nyamuk penyebat malaria $(99,5 \%)$,tanda dan gejala penyakit malaria $(99,5 \%)$, dan pencegahar penyakit malaria $(99,5 \%)$.

\section{Sistem Informasi Geografis \\ Penderita Malaria pada \\ Kelurahan Cereme Taba Kota \\ Lubuklinggau/Hutrianto, $\mathrm{dkk} / 2019$}

Sistem informasi geografis penderita malaria yang dihasilkan dibuat secarc terstruktur menggunakan metode pengembangan waterfall. sistem informasi yang dihasilkan dapat menampilkan informasi sebarang penderita malaria sehingga dapat dijadikan sebagai penyedia data penderita malaria sistem informasi geografis penderita malaria juga dapat berfungsi dengar baik sesuai hasil pengujian yang menyatakan semua komponen berfungs secara normal.

\footnotetext{
Game Edukasi Penyakit Malaria

Dan Cara

Pencegahannya/Mahafi, $\mathrm{dkk} / 2013$
}

$--$

mer

Hasil pengujian yang dilakukan oleh 30 anak- anak usia $9-10$ tahur
menunjukkan bahwa rata- rata $98 \%$ responden merasa memperoleh ilmı
pengetahuan berkaitan dengan penyakit malaria, mudah dan menyenangkan untuk dimainkan. 
Berbasis Web Penerapan

Forward Chaining Untuk

Mendiagnosa Penyakit Malaria

Dan Pencegahanya/Febrianti, $\mathrm{dkk} / 2017$
Metode Forward Chaining dapat digunakan untuk melakukar penelusuran dalam menanggulangi penyakit malaria. Sistem yan dirancang dapat memberikan informasi mengenai gejala serta solus dari penyakit malaria yang didapat dari seorang pakar untul menanggulangi penyakit malaria dan dapat digunakan kapan pun, serti tidak membutuhkan waktu yang lama dalam mendiagnosanya.

Sistem yang dibuat menggunakan bahasa pemrograman php dar database mysql. Sistem pakar ini dibuat untuk membantu kerja dokteı dan memudahkan masyarakat untuk mendiagnosa penyakit malaric serta upaya pencegahannya.

\begin{tabular}{ccl}
\hline Identifikasi Plasmodium & 100 & Tidak ditemukan parasit malaria pada sampel darah yang ditelit \\
Malaria Di Desa Beringin Jaya & & $\begin{array}{l}\text { terhadap masyarakat Desa Beringin Jaya, dilakukan } \\
\text { mikroskopik. }\end{array}$ \\
Kecamatan Oba Tengah Kota & & \\
Tidore & &
\end{tabular}

Kepulauan/Puasa,dkk/20I8

Obat Anti Malaria/Emil, Azlin/2016
Penggunaan obat anti malaria baru perlu dibatasi, diperuntukkan hanye pada kasus yang gagal dengan obat standar. Untuk mendapatkan oba1 anti malaria yang mendekati ideal dan untuk memperlambat terjadiny: alur P.falciparum resisten terhadap obat dianjurkan menggunakar kombinasi obat yang sesuai.

\begin{tabular}{|c|c|c|}
\hline $\begin{array}{l}\text { Efektifitas Vaksinasi dan } \\
\text { Pengasapan pada Model } \\
\text { Epidemik Transmisi } \\
\text { Penyakit } \\
\text { Malaria/Resmawan/2019 }\end{array}$ & - & $\begin{array}{l}\text { Vaksinasi pada manusia dan pengasapan pada nyamuk memilik } \\
\text { pengaruh terhadap dinamika populasi manusia dan nyamuk yan̨̧ } \\
\text { ditunjukkan dengan bilangan reproduksi dasar. Hal tersebu1 } \\
\text { menunjukkan bahwa jumlah individu terinfeksi semakin berkurang } \\
\text { sehingga penyakit tidak akan menyebar dan dalam jangka waktı } \\
\text { tertentu akan menghilang dari populasi. }\end{array}$ \\
\hline $\begin{array}{l}\text { Hubungan Faktor Lingkungan } \\
\text { Fisik dan Perilaku Penghuni } \\
\text { Rumah Dengan Kejadian } \\
\text { Penyakit Malaria Di Wilayah } \\
\text { Kerja Puskesmas Kokap II, } \\
\text { Kabupaten Kulon Progo, } \\
\text { Daerah Istimewa } \\
\text { Yogyakarta/Dewanti,dkk/2016 }\end{array}$ & 37 & $\begin{array}{l}\text { Terdapat hubungan antara keberadaan langit-langit, jenis dinding } \\
\text { keberadaan resting places, breeding places, aktivitas luar rumah } \\
\text { penggunaan pakaian panjang, penggunaan kelambu, dan kegiatan bersit } \\
\text { lingkungan dengan kejadian penyakit malaria di Wilayah Kerja } \\
\text { Puskesmas Kokap II. Tidak terdapat hubungan antara suhu,kelembaban } \\
\text { intensitas pencahayaan, keberadaan kawat kasa, keberadaar } \\
\text { kandang,dan penggunaan obat nyamuk dengan kejadian penyaki1 } \\
\text { malaria diWilayah Kerja Puskesmas Kokap II. }\end{array}$ \\
\hline
\end{tabular}

\begin{tabular}{cll}
\hline Faktor-Faktor Yang & 220 & Faktor-faktor yang terbukti berhubungan dengan perilaku pencegahar \\
Berhubungan Dengan Perilaku & penyakit malaria adalah jenis kelamin,pendidikan,pekerjaan dar \\
Pencegahan Penyakit Malaria & pengetahuan.Sedangkan umur, pendapatan, sikap dan keterpajanar \\
Pada Masyarakat Di Desa & penyuluhan terbukti tidak berhubungan.
\end{tabular}

Karyamukti Kecamatan

Cibalong Kabupaten Garut

Provinsi Jawa Barat

/Farihatun,dkk/2016 


$\begin{array}{cl}\text { Hubungan Faktor Individu } & \text { Faktor individu (pengetahuan,persepsi, penggunaan kelambu, penggunaar } \\ \text { Dan Lingkungan Rumah } & \text { obat anti nyamuk, penggunaan kawat kasa,penutup tubuh, aktivitas k€ } \\ \text { Dengan Malaria Di Punduh } & \text { luar rumah malam dan pekerjaan) merupakan faktor risiko. Fakto } \\ \text { Pedada Kabupaten Pesawaran } & \text { Lingkungan perumahan (kondisi perumahan,lingkungan perindukar } \\ \text { Provinsi Lampung } & \text { nyamuk, pemeliharaan ternak dan jarak rumah dengan perindukar } \\ \text { Indonesia/Ernawati, dkk/20ll } & \text { nyamuk) merupakan faktor risiko. }\end{array}$

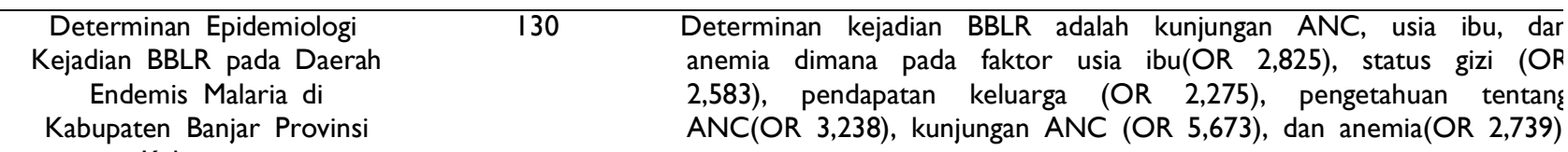

Kalimantan

Selatan/Tazkiah,dkk/2013

\begin{tabular}{|c|c|c|}
\hline $\begin{array}{l}\text { Peranan Ekosistem Hutan } \\
\text { Mangrove Pada Imunitas } \\
\text { Terhadap Malaria: Studi Di } \\
\text { Kecamatan Labuhan Maringgai } \\
\text { Kabupaten Lampung } \\
\text { Timur/Putra,Kartika dkk/20I5 }\end{array}$ & - & $\begin{array}{l}\text { Ada pengaruh ekosistem hutan mangrove baik faktor intrinsik maupur } \\
\text { faktor ekstrinsik pada imunitas masyarakat terhadap penyakit malaria. }\end{array}$ \\
\hline $\begin{array}{c}\text { Tindakan Pencegahan Malaria } \\
\text { Di Desa Sudorogo } \\
\text { Kaligesing/Alami,dkk/2016 }\end{array}$ & 40 & $\begin{array}{l}\text { Variabel yang menunjukkan adanya hubungan yang bermakna dengar } \\
\text { kejadian malaria di wilayah penelitian adalah kebiasaan tidak memaka } \\
\text { kelambu pada saat tidur malam.. Tindakan masyarakat yang meliput } \\
\text { kebiasaan berada diluar rumah malam hari; kebiasaan melakukar } \\
\text { kegiatan penyehatan lingkungan; kebiasaan tidak memakai obat ant } \\
\text { nyamuk saat tidur malam; kebiasaan tidak memakai repellent saa1 } \\
\text { aktivitas diluar rumah malam hari; dan kebiasaan tidak memakai baju } \\
\text { lengan panjang dan celana panjang saat keluar rumah malam har } \\
\text { tidak menunjukkan adanya hubungan yang bermakna dengan kejadiar } \\
\text { malaria di wilayah penelitian. }\end{array}$ \\
\hline
\end{tabular}

\footnotetext{
Konstruksi Bilangan

Reproduksi Dasar pada

Model Epidemik SEIRS-SEI

Penyebaran Malaria dengan Vaksinasi dan

Pengobatan/Resmawan,dkk/20 I
}

Berdasarkan hasil rekonstruksi, diperoleh rumusan bilangan reproduks sebagaimanayang tulis pada persamaan. Perlakuan (treatment) yan diberikan memiliki pengaruh terhadap dinamika populasi manusia dar nyamuk yang ditunjukkan dengan bilangan reproduksi. Jika efektivitas perlakuan ditingkatkan maka bilangan reproduksi menurun. Jumlar individu terinfeksi semakin berkurang, sehingga penyakit tidak akar menyebar dan dalam jangka waktu tertentu akan menghilang dar populasi. 
Malaria Pada Masa

Kehamilan/Rusjdia, dkkl/2012

Malaria merupakan penyakit tropis yang disebabkan oleh parasi Plasmodium dan disebarkan melalui gigitan nyamuk. Diperkirakan 21 s juta penduduk dunia terinfeksi malaria dan sebanyak $660.00 \mathrm{C}$ diantaranya meninggal setiap tahun. Penyakit ini dapat menyeran semua individu tanpa membedakan umur dan jenis kelamin dan tidal terkecuali wanita hamil. Wanita hamil termasuk golongan yang rentar untuk terkena malaria sehubungan dengan penurunan imunitas $d$ masa kehamilan. Malaria pada kehamilan dapat menimbulkan berbaga keadaan patologi pada ibu hamil dan janin yang dikandungnya. Pada ibu hamil, malaria dapat mengakibatkan timbulnya demam, anemia hipoglikemia, edema paru akut, gagal ginjal bahkan dapat menyebabkar kematian. Pada janin yang dikandung oleh ibu penderita malaria dapa terjadi abortus, lahir mati, persalinan prematur, berat badan lahit rendah, dan kematian janin. Keadaan patologi yang ditimbulkan in sangat tergantung pada status imunitas, jumlah paritas dan umur ibc hamil.

\begin{tabular}{|c|c|c|}
\hline $\begin{array}{c}\text { Determinan Kejadian Malaria } \\
\text { di Wilayah Endemis Provinsi } \\
\text { Sumatera } \\
\text { Selatan/Hasyim,dkk/20l4 }\end{array}$ & 240 orang & $\begin{array}{l}\text { Faktor risiko lingkungan kejadian malaria adalah breeding place } \\
\text { beberapa variabel yang tidak berhubungan dengan malaria adalah jaral } \\
\text { rumah ke breeding place, penggunaan kelambu, penggunaan obat ant } \\
\text { nyamuk, dan kebiasaan keluar rumah pada malam hari. Determinar } \\
\text { utama kejadian malaria hasil analisis multivariate adalah breedin̨ } \\
\text { place. }\end{array}$ \\
\hline
\end{tabular}

$\begin{array}{cl}\text { Profil Penyakit Malaria Pada } & \text { Hasil penelitian ini menunjukkan kecepatan dan ketepatan penanganar } \\ \text { Penderita Rawat Inap Di } & \text { di rumah sakit tersebut masih kurang dilihat dari jenis pengobatan } \\ \text { Rumah Sakit Umum Daerah } & \text { dimana ditemukan penggunaan obat antimalaria hanya sekitar } 6-37 \% \\ \text { Kota } & \text { yang diberikan secara benar dan ada sekitar I-I0 \% yanई } \\ \text { Bitung/Purwanto,dkk/20I3 } & \text { penggunaannya masih salah. Juga diagnosis malaria secara klinis hanya } \\ & \text { dijumpai pada } 60 \text { kasus (36\%) plasmodium positif dan diagnosis } \\ \text { masuk terbanyak adalah observasi febris. }\end{array}$

Faktor Lingkungan dan Perilaku Masyarakat Tentang

Malaria di Kecamatan Kupang

Timur Kabupaten

Kupang/Ngambut,dkk/2013
185 rumah

Prevalensi malaria klinis adalah $108(14,4 \%)$ pada satu tahun terakhir Gambaran faktor lingkungan rumah penderita malaria yaitu dindin rumah terbuat dari bebak dan papan masing-masing $43,6 \%$ dan $7,9 \%$ Selain itu, atap rumah terbuat dari alang- alang atau daun lontaı $(21,1 \%)$. Sementara letak rumah dekat dengan breeding place: nyamuk anopheles, yaitu sawah dan lagoon sebanyak (84\%).

Gambaran perilaku masyarakat dalam mencegah mencegah malaric menunjukkan 5,7\% masyarakat tidak melakukan apapun untuk melindungi diri dari gigitan nyamuk. Sebanyak 74,4\% masyaraka kadang-kadang menggunakan kelambu. Dalam hal perilaku pencariar pengobatan, sebanyak $49 \%$ masyarakat menggunakan obat tradisional membeli obat di warung terdekat dan ada yang tidak melakukar apapun. Selain itu, sebagian besar penderita mencari pertolongar kepada tenaga kesehatan setelah lebih dari empat hari mendapa gejala.

Deteksi Penyakit Malaria

Menggunakan Convolutional

Neural Network Berbasis

Saliency/Yohannes, dkk/2020

Pada penelitian ini dilakukanlah pengujian terhadap metode salienc) dan CNN untuk masalah pendeteksian penyakit malaria. Skenaric pengujian dilakukan dengan membandingkan metode saliency, yaitı Region Contrast Saliency, Frequency-tuned saliency, Spectral Residual dan Histogram Contrast.

Metode saliency terbaik dalam mendeteksi penyakit malaria didapatkar oleh metode frequency-tuned salient dengan akurasi sebesar 90,32\% dibandingkan dengan metode saliency yang lain, yaitu $62,67 \%$ untul region contrast saliency, $50 \%$ untuk spectral residual saliency, dar $79,06 \%$ untuk histogram contrast saliency.

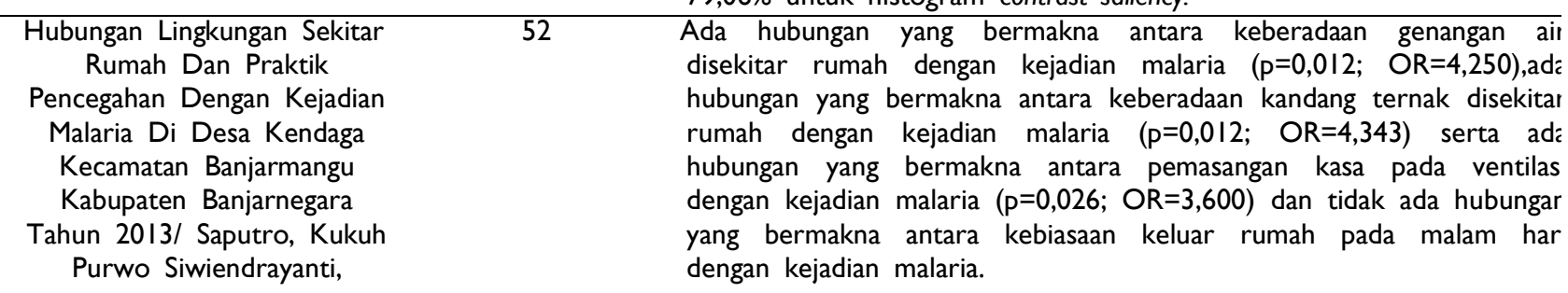




\begin{tabular}{l}
\hline Potensi Kemunculan Kembali $\quad$ II20 orang \\
Malaria Di Kabupaten \\
Pangandaran/ Hakim, Lukman \\
Wahono, Tri Ruliansyah, \\
Andri Kusnandar, Asep \\
Jajang/2018
\end{tabular}

Faktor yang memiliki potensi untuk kemunculan kembali malaria $d$ wilayah kabupaten pangandaran jawa barat yang paling dominan adalat mobilitas penduduk dari daerah endemis malaria di wilayah lain.

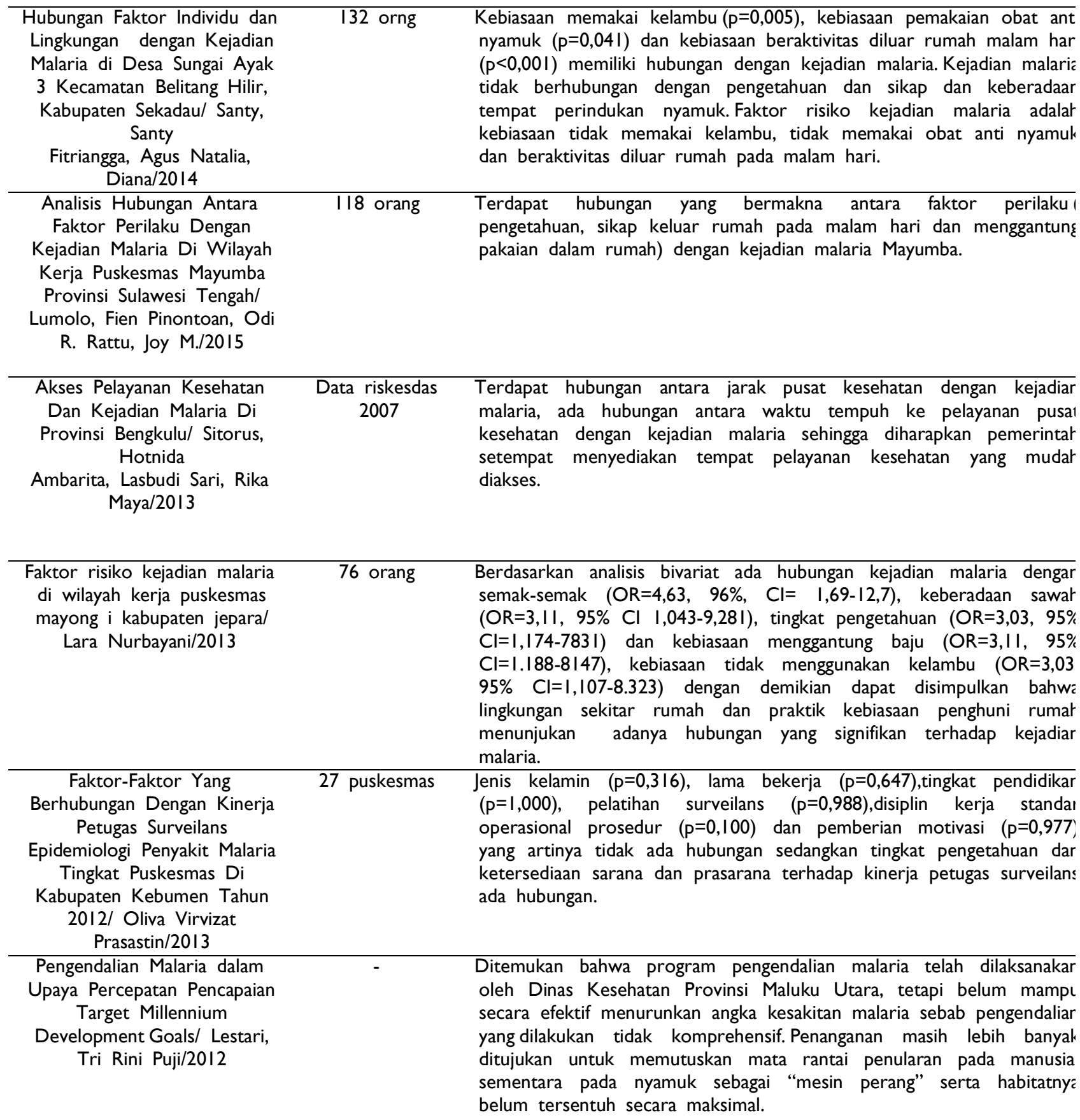




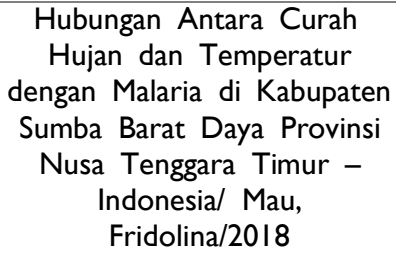

Data sekunder

Hasil uji statistik menunjukkan, tidak ada hubungan yang signifikar antara kasus malaria dengan curah hujan dan temperatur $(P>0,05)$. $U j$ statistik antara infeksi Plasmodium falciparum dan curah hujar menunjukkan hubungan yang signifikan $(P<0,05)$ namun antara infeks P.vivax dengan curah hujan tidak ada hubungan yang signifikar $(P>0,05)$. Disimpulkan, terdapat hubungan yang signifikan antara infeks P.falciparum dengan curah hujan, sedangkan infeksi P.vivax dan infeks campur tidak ada hubungan yang signifikan dengan curah hujar maupun temperatur. Infeksi P.falciparum dan infeksi campur berangsur tinggi pada akhir dan awal musim hujan

\section{PEMBAHASAN}

\section{Perilaku dan Sikap Masyarakat}

Perilaku manusia dapat berakibat bagi kesehatan baik secara langsung maupun secara tidak langsung, akibatnya terhadap pemaanfaatan pelayanan kesehatan, kualitas dan kuantitas penduduk serta lingkungan. Perilaku manusia memiliki pengaruh yang besar dalam menentukan derajat kesehatan. Sikap adalah kemauan untuk bertindak tapi belum merupakan pelaksanaan tindakan. Sikap positif terhadap nilai-nilai kesehatan tidak selalu terwujud dalam satu tindakan nyata. Hal ini dikarenakan oleh alasan bahwa suatu tindakan tergantung situasi dan kondisi saat itu dan dukungan orang disekitarnya.

Kemenkes (2014) mengatakan bahwa tingkat kesadaran masyarakat akan bahaya malaria dapat berdampak pada kesediaan masyarakat untuk melaksanakan upaya pencegahan dalam menanggulangi kemungkinan terkena malaria. Kesadaran masyarakat dapat dilihat dari tindakan pencegahan yang dilakukan seperti(I) Kebiasaan berada di luar rumah sampai larut malam, (2) Melakukan kegiatan kesehatan lingkungan,

Memakai kelambu.Adapun Tujuan dari pemakaian kelambu saat tidur adalah untuk membatasi nyamuk yang terjangkit infeksi menggigit orang yang sehat dan nyamuk yang sehat menggigit orang sakit, (4) Menggunakan obat nyamuk rumah tangga. Insektisida rumah tangga adalah produk anti nyamuk yang sering digunakan masyarakat seperti obat anti nyamuk bakar maupun obat anti nyamuk semprot (5) Penggunaan penolak nyamuk. Fungsi dari penolak ini adalah untuk menolak serangga khususnya nyamuk dan mencegah adanya kontak langsung dengan nyamuk. Penolakan dikatakan baik apabila nyaman digunakan di kulit, tidak menimbulkan iritasi, tidak terasa panas atau lengket jika digunakan, dan berbahan dasar alami, (6) Penggunaan penutup badan. Penggunaan pakaian yang tertutup sangat membantu dalam mencegah gigitan nyamuk terlebih jika melakukan kegiatan di malam hari seperti memancing, ronda malam, berkemah ataupun masuk hutan, (7) Pemasangan kawat kasa pada pintu dan jendela. Upaya ini bertujuan agar nyamuk tidak masuk ke dalam rumah.

Penyebab malaria yang diakibatkan oleh kegiatan yang dilakukan di luar rumah pada malam hari, berkaitan dengan kebiasaan beberapa jenis nyamuk yang ada kegiatan pada malam hari. Nyamuk yang eksofagik adalah nyamuk yang banyak menggigit di luar rumah, tetapi bisa masuk ke dalam rumah bila manusia merupakan sasaran utama yang disukai. Penggunaan kelambu saat tidur merupakan upaya yang paling efektif untuk mencegah digigit nyamuk dibandingkan dengan upaya yang lain. Tujuan memakai kelambu pada malam hari ini adalah mengurangi kontak antara manusia dengan nyamuk. Penggunaan kelambu pada malam hari sebab aktivitas nyamuk menggigit manusia sangat tinggi oleh nyamuk endofagik. Kebiasaan menggantung pakaian di dalam rumah merupakan kebiasaan yang kurang baik. Dilihat dari karakteristik nyamuk terdapat beberapa golongan 
nyamuk yang memiliki sifat suka menempel di tempat yang lembab dan redup dalam rumah setelah menghisap darah misalnya menempel di tembok. Bila terdapat banyak pakaian yang menggantung dapat digunakan sebagai tempat persembunyian nyamuk. Hal ini tentu akan meningkatkan potensi nyamuk untuk kontak dengan manusia. Kebiasaan masyarakat pemakaian obat anti nyamuk juga merupakan faktor yang efektif dalam pencegahan penularan penyakit malaria. Obat anti nyamuk biasanya mengandung zat kimia sintetik (allterin, transflutrin, bioallethrin, diethyltoluamide, esbiothrin dan lain-lain) yang sudah dibentuk sesuai kebutuhan seperti obat nyamuk bakar, elektrik, semprot dan oles.

\section{Faktor Lingkungan}

Penyakit malaria dapat disebabkan oleh beberapa faktor yang ada. Faktor - Faktor tersebut yaitu faktor lingkungan rumah (keberadaan kandang ternak, keberadaan semak-semak dan keberadaan sawah berair); faktor lingkungan fisik rumah (suhu, kelembaban, keberadaan kawat pada ventilasi, keberadaan langit langit rumah, dan kerapatan dinding rumah). Penyebaran penyakit malaria bergantung pada interaksi antara agen pembawa, pejamu dan lingkungan. Lingkungan yang berperan dalam perkembangan bionomik nyamuk adalah lingkungan fisik dan lingkungan biologik. Prabowo (2004) mengatakan bahwa keadaan lingkungan berpengaruh besar terhadap ada tidaknya kejadian malaria di suatu daerah. Adanya danau air payau, genangan air dihutan, persawahan, tambak ikan, pembukaan hutan dan pertambangan di suatu daerah akan meningkatkan kemungkinan timbulnya penyakit malaria karena tempat-tempat tersebut merupakan tempat penyebaran nyamuk malaria. Nyamuk Anopheles sebagai agen pembawa penyakit malaria merupakan salah satu nyamuk yang menyukai tempat - tempat yang dekat dengan tanah. Selain semak-semak dan kebun nyamuk juga menyukai area persawahan yang terdapat genangan air sebagai salah satu tempat perkembangbiakan mereka (breeding place). Akan sulit ditemukan jentik nyamuk pada area persawahan yang sedang aktif ditanami / sedang dialiri air (sawah yang mengandung pestisida), namun akan mudah ditemukan jentik nyamuk pada area persawahan yang sedang tidak ditanami (sawah yang tidak mengandung pestisida).

Pada penelitian yang dilakukan oleh Saputro (2015) diketahui kondisi lingkungan di Desa Kendaga mendukung untuk tempat kumpulan nyamuk Anopheles karena banyak terdapat genangan air, dari hasil penelitian di lapangan menunjukan $51,92 \%$ responden ditemukan parit/selokan yang dapat menampung genangan air di sekitar rumah, berupa parit/selokan limbah rumah tangga maupun genangan air yang terdapat di sekitar perkebunan salak, kurangnya perhatian masyarakat akan sanitasi lingkungan sekitar merupakan faktor penting dalam perkembangbiakan vektor malaria di daerah ini. Dengan sanitasi yang buruk dan tersedianya genangan air yang disukai nyamuk Anopheles meletakan telur mereka untuk berkembangbiak, maka akan meningkatkan populasi nyamuk di daerah ini. Hal tersebut didukung dengan kelembaban di Desa Kendaga yang berkisar antara 45 - 60\% dimana berdasarkan teori Harjianto (2010) pada kelembaban yang tinggi nyamuk menjadi lebih aktif dan lebih sering menggigit, sehingga meningkatkan penularan malaria.

Ernawati (20II) melakukan penelitian di Kabupaten Pesawaran Provinsi Lampung, didapatkan hasil bahwa pemeliharaan ternak berisiko untuk terinfeksi malaria adalah sebesar I,I0 kali dibandingkan individu yang tinggal di rumah tangga yang memiliki peternakan yang tidak berisiko. Pemeliharaan ternak yang berisiko adalah ternak yang tidak mempunyai kandang atau ada 
kandangnya tetapi dekat dengan rumah. Semakin dekat dengan rumah, semakin berisiko terjadinya malaria. Menurut Putra (20II) yang melakukan penelitian dampak ekosistem hutan mangrove diketahui bahwa sanitasi sangat mempengaruhi perkembang biakan nyamuk. Sanitasi yang baik mampu memusnahkan habitat nyamuk Anopheles sp.yang sudah keluar dari habitat yaitu mangrove menuju perkampungan. Eradikasi tersebut meliputi hilangnya tempat-tempat lembab ataupun tampungan-tampungan air hujan yang disebabkan oleh adanya tumpukan-tumpukan sampah yang tidak terkelola secara baik.

Keramaian nyamuk Anopheles dapat mengakibatkan meningkatnya kasus malaria pada bulan berikutnya. Hasil ini sesuai dengan masa inkubasi intrinsik parasit malaria, mulai dari masuknya parasit ke dalam tubuh manusia sampai dengan timbulnya gejala klinis Plasmodium falciparum membutuhkan waktu 8-II hari, Plasmodium vivax membutuhkan waktu 12-17 hari. Kepadatan nyamuk Anopheles 40,5\% dipengaruhi oleh cuaca. Cuaca yang mendung mengakibatkan jumlah uap air yang terdapat dalam udara lebih banyak. Pada daerah pantai mempunyai kelembaban udara yang relatif lebih tinggi sehingga penguapan air laut relatif lebih besar. Cuaca dingin mengakibatkan kelangsungan hidup dan kebiasaan nyamuk menghisap lebih tinggi. Cuaca yang panas akan memperpendek umur nyamuk, sebaliknya cuaca dingin memperpanjang masa hidup nyamuk. Pada cuaca yang dingin, nyamuk akan menjadi lebih aktif dan lebih sering menggigit. Peningkatan kelembaban udara dan curah hujan berbanding lurus dengan peningkatan kepadatan nyamuk. Cuaca tidak mempunyai hubungan bermakna dengan konsistensi nyamuk Anopheles.

\section{KESIMPULAN}

Malaria masih menjadi penyakit yang tinggi kasusnya di Indonesia untuk setiap tahunnya. Banyak faktor yang menentukan risiko terjadinya malaria, terutama jenis spesies nyamuk Anopheles, perilaku manusia dan faktor lingkungan rumah. Suatu perubahan dari faktor yang penyebab Malaria akan mempengaruhi risiko terjadinya malaria. Faktor risiko malaria di Indonesia terdiri dari faktor perilaku dan sikap masyarakat (aktivitas malam hari, penggunaan obat anti nyamuk, penggunaan kelambu), faktor lingkungan dan lingkungan fisik tempat tinggal (keberadaan kandang ternak, keberadaan semak-semak, keberadaan sawah berair, suhu, kelembaban, keberadaan kawat pada ventilasi, keadaan langit - langit rumah, dan kerapatan dinding rumah). Salah satu cara untuk mencegah dan menanggulangi malaria dengan cara meningkatkan sanitasi individu dan lingkungan.

\section{UCAPAN TERIMA KASIH}

Literature review ini dapat dilaksanakan dengan baik berkat bantuan dari berbagai pihak, untuk itu diucapkan terima kasih kepada yang terlibat dan almamater Pasca Sarjana Fakultas Kesehatan Masyarakat Universitas Sriwijaya.

\section{REFERENSI}

I. A. B.S. Duarsa, 'Dampak Pemanasan Global Terhadap Risiko Terjadinya Malaria', J. Kesehat. Masy. Andalas, vol. 2, no. 2, p. I8I, 2008, doi: 10.24893/jkma.2.2.18I-I85.2008.

2. K. P. Saputro and A. Siwiendrayanti, 'Hubungan Lingkungan Sekitar Rumah Dan Praktik Pencegahan Dengan Kejadian Malaria Di Desa Kendaga Kecamatan Banjarmangu Kabupaten Banjarnegara Tahun 2013', Unnes J.Public Health., vol. 4, no. 2, Pp. 76-83, 2015, doi: 10.15294/ujph.v4i2.5038.

3. F. Mau, 'Hubungan Antara Curah Hujan dan Temperatur dengan Malaria di Kabupaten Sumba Barat Daya Provinsi Nusa Tenggara Timur - Indonesia', Bul. Penelit. Kesehat., vol. 46, 
no. 2, Pp. 129-134, 2018, doi: 10.22435/bpk.v46i2.309.

4. Hutrianto and F. Syakti, 'Sistem Informasi Geografis Penderita Malaria pada Kelurahan Cereme Taba Kota Lubuklinggau', Digit. Zo.J. Teknol. Inf. dan Komun., vol. 10, no. 2, pp. 178-188, 2019, doi: 10.31849/digitalzone.v10i2.3134.

5. A. Farihatun and Z. Mamdy, 'Faktor-Faktor Yang Berhubungan Dengan Perilaku Pencegahan Penyakit Malaria Pada Masyarakat Di Desa Karyamukti Kecamatan Cibalong Kabupaten Garut Provinsi Jawa Barat', J. Kesehatan. Bakti Tunas Husada J.llmu-ilmu Keperawatan, Anal. Kesehat. dan Farm., vol. 15, no. I, p. 109, 20I6, doi: 10.36465/jkbth.vI5il.I57.

6. R. Alami and R. Adriyani, 'Tindakan Pencegahan Malaria Di Desa Sudorogo the Prevention of Malaria At Sudorogo Village Kaligesing', J. Promkes, vol. 4, no. 2, Pp. I99-2II, 2016, doi: 10.20473/jpk.V4.12.2016.199-2II.

7. S. Santy, A. Fitriangga, and D. Natalia, 'Hubungan Faktor Individu dan Lingkungan dengan Kejadian Malaria di Desa Sungai Ayak 3 Kecamatan Belitang Hilir, Kabupaten Sekadau', ejournal Kedokt. Indones., vol. 2, no. I, 20I4, doi: $10.23886 /$ ejki.2.3।86.

8. Lara Nurbayani, 'FAKTOR RISIKO KEJADIAN MALARIA DI WILAYAH KERJA PUSKESMAS MAYONG I KABUPATEN JEPARA', J. Kesehat. Masy., vol. 2, no. I, PP. I-I0, 20I3, [Online]. Available:

http://ejournals I.undip.ac.id/index.php/jkm.

9. K. s Ernawati, B. Soesilo, and A. Duarsa, 'Hubungan Faktor Individu Dan Lingkungan Rumah Dengan Malaria Di Punduh Pedada Kabupaten Pesawaran Provinsi Lampung Indonesia 2010', Makara Kesehatan., vol. I5, no. 2, Pp. 5I-57, 20II, doi: I0.7454/msk.vI5i2.916.

10. A. Kartika Putra, S. Bakri, and B. Kurniawan, "Peranan Ekosistem Hutan Mangrove Pada Imunitas Terhadap Malaria: Studi Di Kecamatan Labuhan Maringgai Kabupaten Lampung Timur", J. Sylva Lestari, vol. 3, no. 2, p. 67, 2015, doi: 10.23960/js|2367-78.

II. S. SUWITO, U. K. HADI, S. H.SIGIT, and S. SUKOWATI, 'Hubungan Iklim, Kepadatan Nyamuk Anopheles dan Kejadian Penyakit Malaria', J. Entomol. Indones., vol. 7, no. I, p. 42, 2015, doi: 10.5994/jei.7.1.42.
12. C. S. Akay, J.S.B.Tuda, and V.D. Pijoh, 'Gambaran Pengetahuan Masyarakat Tentang Penyakit Malaria Di Kecamatan Silian Raya Kabupaten Minahasa Tenggara', J.e-Biomedik, vol. 3, no. I, 20I5, doi: I0.35790/ebm.3.I.20I5.742I.

13. A. G. Mahafi and G. Hermawan, 'Game Edukasi Penyakit Malaria Dan Cara Pencegahannya', J. Ilm. Komput. dan Inform., vol. 2, no. 2, Pp. 1926, 2013, [Online]. Available: http://komputa.if.unikom.ac.id/jurnal/gameedukasi-penyakit-malaria. Ia.

14. E. L. Febrianti and T. Christi, 'Penerapan Forward Chaining Untuk Mendiagnosa Penyakit Malaria Dan Pencegahanya Berbasis Web', Jurteksi, vol. 4, no. I, Pp. 93-100, 2017, doi: I0.33330/jurteksi.v4il.32.

I5. S. R. Rusjdi, 'Malaria Pada Masa Kehamilan', Maj. Kedokt. Andalas, vol. 36, no. 2, p. 173, 2012, doi: 10.22338/mka.v36.i2.pl73-I78.20I2.

16. H. Hasyim, A. Camelia, and N. F. Alam, 'Determinan Kejadian Malaria di Wilayah Endemis Provinsi Sumatera Selatan', Kesehat. Masy. Nas., vol. 8, no. 7, pp. 291-294, 20I4, doi: http://dx.doi.org/10.21 109/kesmas.v0i0.367.

I7. D. S. Purwanto and R.I. Ottay, 'Profil Penyakit Malaria Pada Penderita Rawat Inap Di Rumah Sakit Umum Daerah Kota Bitung', J. Biomedik, vol. 3, no. 3, Pp. I72-I78, 2013, doi: I0.35790/jbm.3.3.20II.872.

18. K. Ngambut and O. Sila, 'Faktor Lingkungan dan Perilaku Masyarakat Tentang Malaria di Kecamatan Kupang Timur Kabupaten Kupang', Kesmas Natl. Public Heal.J., vol. 7, no. 6, p. 27I, 2013, doi: 10.21109/kesmas.v7i6.37.

19. Y. Yohannes, S. Devella, and K. Arianto, 'Deteksi Penyakit Malaria Menggunakan Convolutional Neural Network Berbasis Saliency', JUITA J.Inform., vol. 8, no. I, p. 37, 2020, doi: 10.30595/juita.v8il.667I.

20. R. Puasa, A. A. H, and A. Kader, 'Identifikasi Plasmodium Malaria Didesa Beringin Jaya Kecamatan Oba Tengah Kota Tidore Kepulauan', J. Ris. Kesehat., vol. 7, no. I, P. 2I, 2018, doi: I0.31983/jrk.v7il.3056. 
21. E. Azlin, 'Obat Anti Malaria', Sari Pediatri., vol. 5, no. 4, P. 150, 2016, doi: I0.14238/sp5.4.2004.I50-4.

22. R. Resmawan, 'Efektifitas Vaksinasi dan Pengasapan pada Model Epidemik Transmisi Penyakit Malaria', Jambura J.Math., vol. I, no. I, Pp. 25-35, 2019, doi: I0.343 I2/jjom.vlil.2004.

23. N. Dewanti, T. Joko, and P. Noviarti, 'Hubungan Faktor Lingkungan Fisik Dan Perilaku Penghuni Rumah Dengan Kejadian Penyakit Malaria Di Wilayah Kerja Puskesmas Kokap li, Kabupaten Kulon Progo, Daerah Istimewa Yogyakarta', J. Kesehat. Masy., vol. 4, no. I, Pp. 4I7-426, 2016.

24. M. Tazkiah, C. U. Wahyuni, and S. Martini, 'Determinan Epidemiologi Kejadian BBLR pada Daerah Endemis Malaria di Kabupaten Banjar Provinsi Kalimantan Selatan', J. Berk. Epidemiologi, vol. I, no. 2, pp. 266-276, 2013, doi: I0.5830/CVJA-20I6-02I.

25. R. Resmawan and N. Nurwan, 'Konstruksi Bilangan Reproduksi Dasar pada Model Epidemik SEIRS-SEI Penyebaran Malaria dengan Vaksinasi dan Pengobatan', J.Mat. Integr., vol. 13, no. 2, p. 105, 2017, doi: |0.24|98/jmi.v|3.n2.|2332.|05-|| 4 .

26. L. Hakim, T. Wahono, A. Ruliansyah, and A. J. Kusnandar, 'Potensi Kemunculan Kembali Malaria Di Kabupaten Pangandaran', ASPIRATOR - J.Vector-borne Dis. Stud., vol. I0, no. I, Pp. 37-48, 20I8, doi: 10.22435/asp.v10il.I54.

27. F. Lumolo, O. R. Pinontoan, and J.M. Rattu, 'Analisis Hubungan Antara Faktor Perilaku Dengan Kejadian Malaria Di Wilayah Kerja Puskesmas Mayumba Provinsi Sulawesi Tengah', J. e-Biomedik, vol. 3, no. 3, 2015, doi: 10.35790/ebm.3.3.20I5.10322.

28. H. Sitorus, L. Ambarita, and R. M. Sari, 'Akses Pelayanan Kesehatan Dan Kejadian Malaria Di Provinsi Bengkulu', Media Penelit.dan Pengemb. Kesehat., vol. 23, no. 4, Pp. I58-164, 20I3, doi: 10.22435/mpk.v23i4.3425.I58-I64.

29. Oliva Virvizat Prasastin, 'Faktor-Faktor Yang Berhubungan Dengan Kinerja Petugas Surveilans Epidemiologi Penyakit Malaria Tingkat Puskesmas Di Kabupaten Kebumen Tahun 2012', Unnes J. Public Health., vol. 2, no. 4, pp. I-II, 20I3, doi: I0.I5294/ujph.v2i4.306I.
30. T.R.P. Lestari, 'Pengendalian Malaria dalam Upaya Percepatan Pencapaian Target Millennium Development Goals', Kesmas Natl. Public Heal.J., vol. 7, no. I, p. 22, 2012, doi: 10.21 l09/kesmas.v7il.72. 